\title{
The use of gamma-irradiation and ultraviolet-irradiation in the preparation of human melanoma cells for use in autologous whole-cell vaccines
}

\author{
Donna H Deacon 1,2, Kevin T Hogan 1,2, Erin M Swanson1, \\ Kimberly A Chianese-Bullock ${ }^{1,2}$, Chadrick E Denlinger ${ }^{1}$, \\ Andrea R Czarkowski ${ }^{1}$, Randy S Schrecengost ${ }^{1}$, James W Patterson ${ }^{3}$, \\ Mark W Teague 3 and Craig L Slingluff Jr*1,2
}

Address: ${ }^{1}$ Department of Surgery, University of Virginia, Charlottesville, VA, 22908, USA, ${ }^{2}$ Human Immune Therapy Center, University of Virginia, Charlottesville, VA, 22908, USA and ${ }^{3}$ Department of Pathology, University of Virginia, Charlottesville, VA 22908, USA

Email: Donna H Deacon -dmh9q@virginia.edu; Kevin T Hogan - kh6s@virginia.edu; Erin M Swanson - ems1119@ecu.edu; Kimberly A Chianese-Bullock - kb9d@virginia.edu; Chadrick E Denlinger - denlingerc@wudosis.wustl.edu; Andrea R Czarkowski - arc7b@virginia.edu; Randy S Schrecengost - rss3k@virginia.edu; James W Patterson - jwp9e@virginia.edu; MarkW Teague - mteague11@comcast.net; Craig L Slingluff* - cls8h@virginia.edu

* Corresponding author

Published: 4 December 2008

BMC Cancer 2008, 8:360 doi:10.1 186/I47|-2407-8-360

This article is available from: http://www.biomedcentral.com/I47I-2407/8/360

(c) 2008 Deacon et al; licensee BioMed Central Ltd.

This is an Open Access article distributed under the terms of the Creative Commons Attribution License (http://creativecommons.org/licenses/by/2.0), which permits unrestricted use, distribution, and reproduction in any medium, provided the original work is properly cited.
Received: 8 May 2008

Accepted: 4 December 2008

\begin{abstract}
Background: Human cancer vaccines incorporating autologous tumor cells carry a risk of implantation and subsequent metastasis of viable tumor cells into the patient who is being treated. Despite the fact that the melanoma cell preparations used in a recent vaccine trial (Mel37) were gamma-irradiated (200 Gy), approximately $25 \%$ of the preparations failed quality control release criteria which required that the irradiated cells incorporate ${ }^{3} \mathrm{H}$-thymidine at no more than $5 \%$ the level seen in the non-irradiated cells. We have, therefore, investigated ultraviolet (UV)-irradiation as a possible adjunct to, or replacement for gamma-irradiation.
\end{abstract}

Methods: Melanoma cells were gamma- and/or UV-irradiated. ${ }^{3} \mathrm{H}$-thymidine uptake was used to assess proliferation of the treated and untreated cells. Caspase- 3 activity and DNA fragmentation were measured as indicators of apoptosis. Immunohistochemistry and Western blot analysis was used to assess antigen expression.

Results: UV-irradiation, either alone or in combination with gamma-irradiation, proved to be extremely effective in controlling the proliferation of melanoma cells. In contrast to gammairradiation, UV-irradiation was also capable of inducing significant levels of apoptosis. UVirradiation, but not gamma-irradiation, was associated with the loss of tyrosinase expression. Neither form of radiation affected the expression of gP I00, MART-I/MelanA, or SI00.

Conclusion: These results indicate that UV-irradiation may increase the safety of autologous melanoma vaccines, although it may do so at the expense of altering the antigenic profile of the irradiated tumor cells. 


\section{Background}

Cellular immune responses to autologous tumor cells have been documented in cancer patients including those with melanoma. Antigens recognized by tumor-specific T cells have been categorized as cancer-testis antigens, differentiation proteins, mutated gene products, widely expressed proteins, and viral proteins [1-3]. Vaccines incorporating synthetic forms of these antigens may be immunogenic, but the ensuing immune response can only be effective if the tumor in the vaccine recipient expresses one or more of the antigens present in the vaccine. This can be problematic because cancer-testis antigens are expressed only in a subset of tumors [4,5]. and differentiation antigens are often down-regulated in metastases [6-11]. Thus, peptide, protein, or DNA-based vaccines currently being tested can potentially stimulate immune responses for which there is no target in a particular patient. Further, such vaccines designed for use in a general population do not contain unique antigens arising from mutated gene products as these antigens would only be useful in the patient whose tumor expresses them [12-14]. Targeting unique antigens might prove advantageous, however, as many of the altered proteins may play a role in the malignant phenotype of the cell $[13,14]$.

An ideal synthetic vaccine would contain each of the antigens expressed by the tumor cells of an individual patient, however, with the limitations of current antigen identification technology this is not yet feasible. Until antigen identification technology can be performed rapidly on a customized basis for each patient, approaches to vaccination with unique tumor antigens or otherwise undiscovered antigens will require incorporation of the autologous tumor tissue in the vaccines. Such approaches include vaccination with autologous tumor cells $[15,16]$, RNA derived from autologous tumor cells $[17,18]$, or heat shock proteins derived from autologous tumor cells $[19,20]$. Autologous tumor cells may be administered as viable cells alone $[15,16]$, as viable cells with dendritic cells (DC) [21], or as cell lysates added to DC [22,23].

A concern for patient safety with autologous tumor cell vaccines is that viable autologous tumor cells could proliferate and metastasize in the host. To prevent this from occurring after vaccination, a standard approach used in human clinical trials has been to pre-treat the tumor cells with 25 to 200 Gy of gamma irradiation [24-29]. We have enrolled patients in one such melanoma vaccine trial using autologous tumor cells (Mel37). To provide optimal patient safety within this trial, the tumor cells were gamma-irradiated (200 Gy) prior to vaccination. As part of the quality assurance release criteria, a ${ }^{3} \mathrm{H}$-thymidine uptake assay was then performed to ensure that the irradiated tumor incorporated ${ }^{3} \mathrm{H}$-thymidine at no more than $5 \%$ of the level found in the non-irradiated tumor.
Our experience with the Mel37 trial has been useful in establishing additional guidelines and procedures to help ensure the safety of autologous tumor cell vaccines. In particular, we demonstrate the resistance of some patients' metastatic tumor cells to 200 Gy gamma-irradiation as demonstrated by the ability to incorporate ${ }^{3} \mathrm{H}$-thymidine despite being given that dose of radiation. We therefore investigated ultraviolet (UV) radiation for its ability to block ${ }^{3} \mathrm{H}$-thymidine uptake and to induce apoptosis of tumor cells. The results from this study demonstrate that the combination of gamma-irradiation and UVirradiation was found to give the best control of tumor cell proliferation in vitro.

\section{Methods}

\section{Tumor tissue collection and human subjects approval}

All research involving human subjects and human tissues was approved by the University of Virginia Institutional Review Board (IRB\# 8577) in accordance with an assurance filed with and approved by the Department of Health and Human Services (BB-IND\# 8932). Tumor specimens were obtained through the Tissue Procurement Facility of the University of Virginia.

\section{Tumor cell preparation}

Tumor specimens collected sterilely from the operating room were cut into $2-8 \mathrm{~mm}$ thick slices and immersed in Hanks' balanced salt solution (HBSS, Life Technologies, Grand Island, NY). The tumor specimen was mechanically dissociated with a sterile scalpel. Remaining tumor fragments were transferred to a $50 \mathrm{ml}$ conical tube with RPMI-1640 (Life Technologies) containing $1 \mathrm{mg} / \mathrm{ml}$ collagenase (Worthington Biochemical Corp., Lakewood, NJ), $10 \mu \mathrm{g} / \mathrm{ml}$ DNAase (Worthington Biochemical Corp.), 2.5 $\mathrm{U} / \mathrm{ml}$ hyaluronidase (Worthington Biochemical Corp.), $100 \mu \mathrm{g} / \mathrm{ml}$ penicillin $\mathrm{G}$ (sodium salt), $100 \mu \mathrm{g} / \mathrm{ml}$ streptomycin sulfate, $0.25 \mu \mathrm{g} / \mathrm{ml}$ amphotericin $\mathrm{B}$, and $5 \%$ autologous serum or human $\mathrm{AB}$ serum (Sigma Chemical Co., St. Louis, MO) and incubated at room temperature. Dissociated tumor cells were washed by centrifugation with HBSS. Cell counts with trypan blue were performed to determine tumor cell viability and yield. Tumor cells were cryopreserved in 10\% DMSO, 90\% autologous serum or human $\mathrm{AB}$ serum using a controlled rate freezer.

\section{Assay medium}

RPMI-1640 was supplemented with 10\% fetal bovine serum, $2 \mathrm{mM}$ L-glutamine, $100 \mathrm{U} / \mathrm{ml}$ penicillin, and 100 $\mu \mathrm{g} / \mathrm{ml}$ streptomycin (complete RPMI).

\section{Gamma irradiation of tumor cell suspensions}

A Gammacell 3000 Elan (MDS Nordion, Ottawa, ON, Canada) with a Cesium-137 source used for gamma irradiation. Tumor cell suspensions at $1-5 \times 10^{6}$ cells $/ \mathrm{ml}$ in complete RPMI were irradiated at $555.5 \mathrm{~Gy} / \mathrm{min}$. 


\section{Ultraviolet irradiation of tumor cell suspensions}

Cell suspensions were plated into 6 -well plates at $2-4 \times 10^{6}$ cell $/ \mathrm{ml}$ in a total volume of $1.5 \mathrm{ml}$ of complete RPMI. The plate was placed on a UV transilluminator box (UVP, Inc., Upland, CA) and exposed to a combination of UVA (84 mJ/ $\left.\mathrm{cm}^{2} / \mathrm{min}\right)$ and UVB $\left(26 \mathrm{~mJ} / \mathrm{cm}^{2} / \mathrm{min}\right)$ for $15 \mathrm{sec}$ to $10 \mathrm{~min}$. A UVA monitor (UVA-400C, National Biological Corp., Twinsburg, OH) and UVB monitor (UVB-500C, National Biological Corp.) were used to measure the UV dose rate.

\section{Combination ultraviolet and gamma irradiation of tumor cells}

Cells were first exposed to UV irradiation and then exposed to gamma irradiation as described above.

\section{Assay of ${ }^{3} \mathrm{H}$-thymidine incorporation after irradiation} Tumor cell suspensions in complete RPMI were plated in $5-6$ replicates at 20,000-50,000 cells $/ 200 \mu \mathrm{l}$ in flat-bottom 96-well plates (Costar, Lowell, MA) and incubated at $37^{\circ} \mathrm{C}$ in a humidified, $5 \% \mathrm{CO}_{2}$ incubator for 5 days. One $\mu \mathrm{Ci}$ of ${ }^{3} \mathrm{H}$-thymidine in $25 \mu \mathrm{l}$ of complete RPMI was then added to each well and the incubation continued for an additional 18-24 h. Cells were then harvested using a MACH IIIM Harvester 96 (Tomtec, Hamden, CT) and the amount of incorporated ${ }^{3} \mathrm{H}$-thymidine in counts per minute (CPM) was determined using a 1450 MicroBeta Trilux Liquid Scintillation and Luminescence Detector (PerkinElmer, Boston, MA). Background ${ }^{3} \mathrm{H}$-thymidine incorporation was initially determined with wells containing only complete medium while later experiments used wells containing a comparable number of cells that had been subjected to three freeze-thaw cycles (freezing in liquid nitrogen followed by thawing in a $37^{\circ} \mathrm{C}$ water bath). As a control, the lymphoblastoid cell line K562 was treated in a similar fashion. Incorporated ${ }^{3} \mathrm{H}$-thymidine was determined as: $\mathrm{CPM}_{\text {cells }}-\mathrm{CPM}_{\text {background }}$ Percent maximal ${ }^{3} \mathrm{H}$-thymidine incorporation was determined as: $\left[\left(\mathrm{CPM}_{\text {irradiated }}-\mathrm{CPM}_{\text {background }}\right) /\left(\mathrm{CPM}_{\text {non-irrdiated }}\right.\right.$ - $\mathrm{CPM}_{\text {back- }}$ ground) $] \times 100$.

\section{Apoptosis assays}

Caspase-3 activity was measured as previously described using DEVD-AFC (Calbiochem, San Diego, CA) as the substrate [30]. DNA fragmentation was measured using a Cell Death Detection ELISA ${ }^{\text {PLUS }}$ kit (Roche, Indianapolis, IN) according to the manufacturer's instructions.

\section{Immunohistochemistry}

To evaluate antigen expression at various time points after irradiation, tumor cell suspensions were pelleted by centrifugation. Cell blocks were made by pelleting the cells, fixing them with $10 \%$ formalin, and then embedding them in paraffin. Immunohistochemistry stains were performed by the Pathology Department using clinical-grade antibodies to gp100 (HMB45, Dako, Carpinteria, CA), tyrosinase (T311, Vector Laboratories, Burlingame, CA), MART-1/MelanA (A103, Dako), and S100 (Dako) and the slides were read by a pathologist (MWT).

\section{Western blot analysis}

Cells were harvested and lysates prepared using NP-40 lysis buffer [31]. Protein concentration was determined using a BCA Protein Assay Kit (Pierce, Rockford, IL). Proteins ( $40 \mu \mathrm{g} /$ lane) were resolved on $4-12 \%$ Bis-Tris polyacrylamide gels and then transferred to PVDF membranes (Pierce, Rockford, IL). After blocking with 1\% bovine serum albumin, the membranes were probed with a rabbit polyclonal antisera to tyrosinase (clone H-109, Santa Cruz Biotechnology, Santa Cruz, CA) and a mouse monoclonal antibody to GAPDH (clone 6C5, Millipore, Billerica, MA). Peroxidase-linked sheep anti-mouse and donkey-anti-rabbit antisera (Amersham Biosciences, Piscataway, NJ) in conjunction with the SuperSignal West Pico Chemiluminescent substrate (Pierce) were used to detect binding of the primary antibodies.

\section{Results \\ Proliferation of gamma-irradiated melanoma cells prepared for autologous vaccination}

Mel37 was an autologous melanoma vaccine trial conducted at the University of Virginia (UVA). To minimize the possibility of outgrowth of the tumor cells in the vaccine recipient, the tumor cells were gamma irradiated (200 Gy) prior to administration. The irradiated tumor cells were then tested for their ability to incorporate ${ }^{3} \mathrm{H}$ thymidine in comparison to the non-irradiated control sample. As part of the lot vaccine release criteria, the ${ }^{3} \mathrm{H}$ thymidine incorporation of the irradiated cells had to be less than $5 \%$ of the ${ }^{3} \mathrm{H}$-thymidine incorporation of the corresponding non-irradiated cells. Vaccine preparations that failed to meet those criteria were not used.

Tumors from thirty-three melanoma patients were included in the study and demonstrated a 9,300-fold range of ${ }^{3} \mathrm{H}$-thymidine incorporation, varying from 18 to 170,014 CPM (Figure 1A). Gamma-irradiation (200 Gy) reduced the ${ }^{3} \mathrm{H}$-thymidine incorporation of twenty-five $(76 \%)$ of these samples below $5 \%$ of the non-irradiated control samples (Figure 1B). The remaining eight irradiated vaccines $(24 \%)$ had a mean ${ }^{3} \mathrm{H}$-thymidine incorporation of $28 \%$ (median 17\%, range, $8 \%-63 \%$ ) in comparison to the non-irradiated control samples. Notably, the ${ }^{3} \mathrm{H}$-thymidine incorporation of irradiated tumor cells from three patients exceeded $40 \%$ of the corresponding non-irradiated samples. Among the eight specimens failing the lot release criteria, five were retested from one to three times with the same results (data not shown).

The fact that 200 Gy of gamma-irradiation failed to reduce the ${ }^{3} \mathrm{H}$-thymidine incorporation of eight of thirty-three 

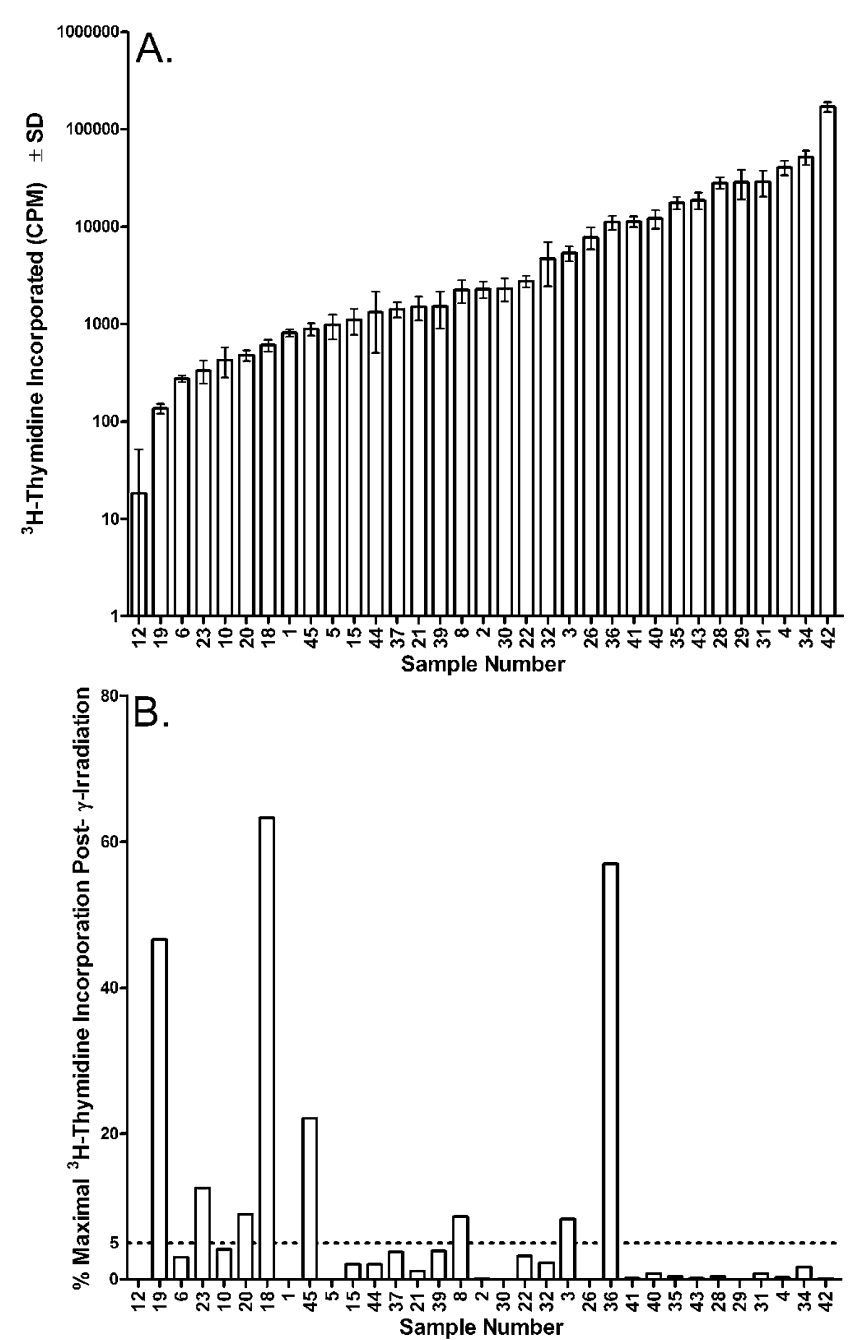

Figure I

${ }^{3} \mathrm{H}$-thymidine incorporation of melanoma cells prior to and following treatment with 200 Gy gamma-irradiation. Human melanoma deposits were resected surgically and the tumors rendered into single cell suspensions by mechanical and enzymatic dissociation. The cell suspensions were then prepared into a tumor cell vaccine and split into samples receiving or not receiving $200 \mathrm{~Gy}$ gamma-irradiation. The non-irradiated and irradiated cells were then cultured in vitro for five days prior to the addition of ${ }^{3} \mathrm{H}$-thymidine for 18 to $24 \mathrm{hr}$. (A) Proliferation in the absence of gamma-irradiation. Samples ordered from lowest to highest proliferation. (B) Proliferation following treatment with 200 Gy gammairradiation. The data are presented as percent maximal ${ }^{3} \mathrm{H}$ thymidine incorporation in comparison to the non-irradiated control. Samples are ordered as in (A). The dashed horizontal bar indicates $5 \%$ maximal ${ }^{3} \mathrm{H}$-thymidine incorporation.

samples below 5\% of the non-irradiated controls prompted us to determine if a more effective means could be found to reduce the ${ }^{3} \mathrm{H}$-thymidine incorporation of the treated samples. These studies, which follow, were con- ducted with melanoma cell lines rather than fresh patient samples, as cells from the lines are not limiting in numbers.

Dose response of gamma-irradiation on the proliferative capacity of melanoma cell lines

The inability of 200 Gy of gamma-irradiation to decrease ${ }^{3} \mathrm{H}$-thymidine incorporation of melanoma cells to less than $5 \%$ of that seen in the corresponding non-irradiated controls could be the result of using too low a dose of irradiation, although the dose chosen is at the upper limit of what has been used in other studies [24-29]. A gammairradiation dose response experiment with four different melanoma cell lines was therefore conducted to determine if $200 \mathrm{~Gy}$ is a reasonable dose. The results indicate that ${ }^{3} \mathrm{H}$-thymidine rapidly decreased through about $50 \mathrm{~Gy}$ and then remained at a low, but measurable level through $200 \mathrm{~Gy}$ (Figure 2A). In no case, however, did the ${ }^{3} \mathrm{H}$-thymidine of the irradiated samples relative to the non-irradiated samples decrease below 5\% (DM6 = 28\%, DM93 = $53 \%$, VMM39 = 14\%, VMM86 = 23\%).

\section{Dose response of UV-irradiation on the ${ }^{3} \mathrm{H}$-thymidine uptake of melanoma cell lines}

The effect of UV-irradiation on the ${ }^{3} \mathrm{H}$-thymidine uptake of melanoma cells was next tested. Adherent monolayers of cells in 6-well plates were exposed to a UV light source for varying amounts of time and at a delivery rate of 84 $\mathrm{mJ} / \mathrm{cm}^{2} / \mathrm{min}$ UVA and $26 \mathrm{~mJ} / \mathrm{cm}^{2} / \mathrm{min}$ UVB. Although melanoma cell line DM93 was less sensitive to lower doses of UV-irradiation than were the other three melanoma cell lines, two minutes of UV-irradiation was sufficient to reduce the ${ }^{3} \mathrm{H}$-thymidine uptake of the irradiated cells to $1.5 \%$ or less of the corresponding non-irradiated cell line (Figure 2B).

\section{Combined effect of gamma-irradiation and UV-irradiation on the ${ }^{3} \mathrm{H}$-thymidine uptake capacity of melanoma cell lines and fresh melanoma cells}

Melanoma cell lines were next subjected to $0-10 \mathrm{~min}$ of UV-irradiation followed by 0 - 200 Gy gamma-irradiation (Figure 3). As in previous experiments, gamma-irradiation alone did not reduce ${ }^{3} \mathrm{H}$-thymidine uptake below $5 \%$ of that of the non-irradiated controls. In contrast, as little as one minute of UV-irradiation was sufficient to drop the ${ }^{3} \mathrm{H}$-thymidine uptake of each of the cell lines to less than $0.5 \%$ of the non-irradiated control. Because the reduction in ${ }^{3} \mathrm{H}$-thymidine uptake with UV-irradiation was nearly complete, the combination of UV-irradiation and gamma-irradiation did not show any additive or synergistic effects within the dose ranges chosen.

Five melanoma cell lines were further treated with gamma-irradiation (200 Gy) alone, UV-irradiation alone ( $2 \mathrm{~min}$ ), or a combination of the two (Figure 4 ). Relative 

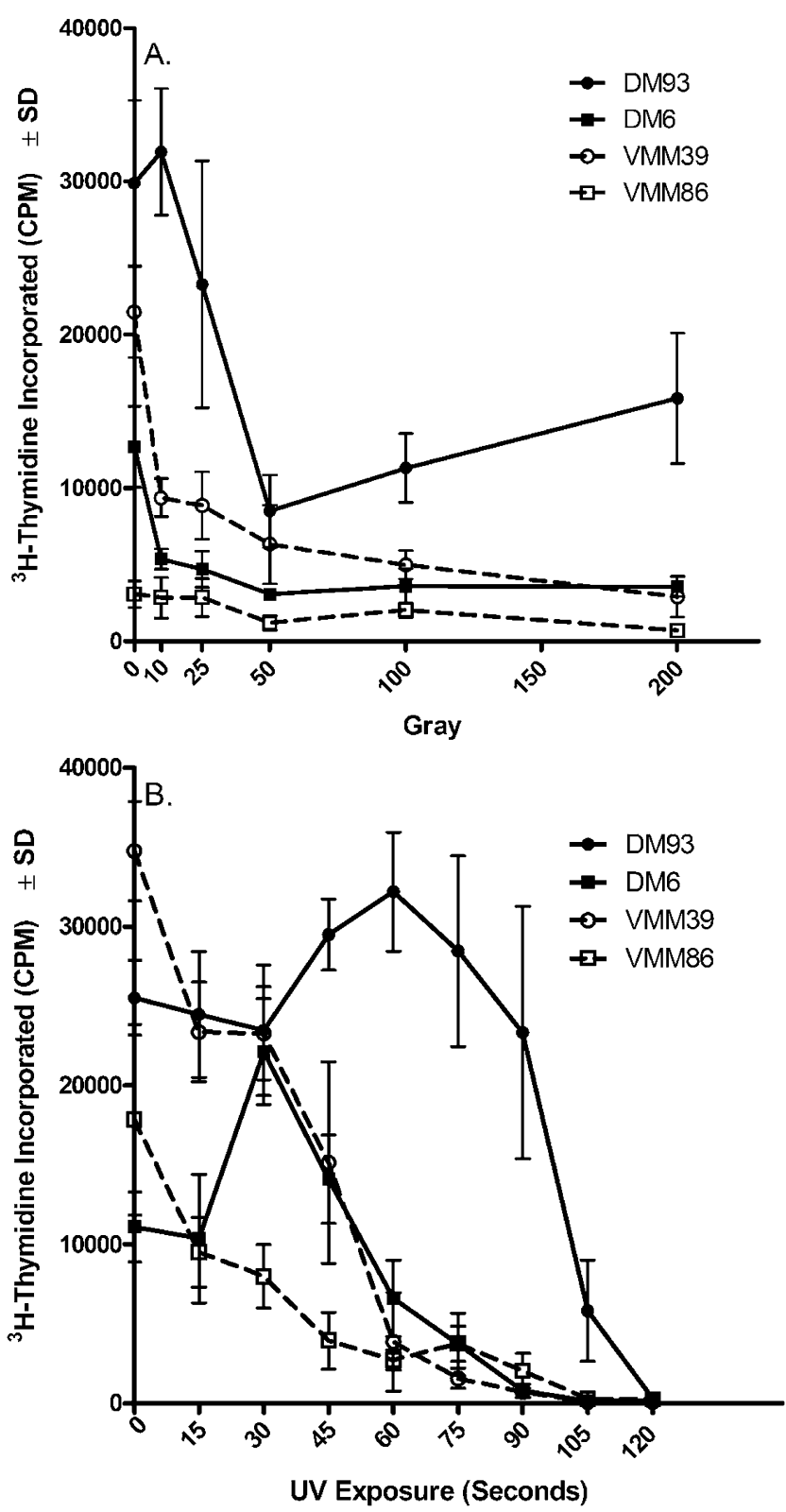

Figure 2

Effect of gamma-irradiation and UV-irradiation dose titration on the ${ }^{3} \mathrm{H}$-thymidine incorporation of melanoma cell lines. Melanoma cell lines, either untreated or treated with the indicated dose of $(A)$ gamma-irradiation or (B) UV-irradiation, were cultured in vitro for five days prior to the addition of $3 \mathrm{H}$-thymidine for 18 to $24 \mathrm{hr}$.

to the non-irradiated controls, gamma-irradiation reduced the ${ }^{3} \mathrm{H}$-thymidine uptake to $31 \%$ (range $=9$ $71 \%$ ), UV-irradiation reduced the ${ }^{3} \mathrm{H}$-thymidine uptake to $2.2 \%$ (range $=0.2-4.8 \%$ ), and the combination of UV and gamma-irradiation reduced the ${ }^{3} \mathrm{H}$-thymidine uptake to $1.1 \%$ (range $=0.0-1.9 \%$ ). Although in each case, UV-irradiation reduced the ${ }^{3} \mathrm{H}$-thymidine uptake to less than $5 \%$,

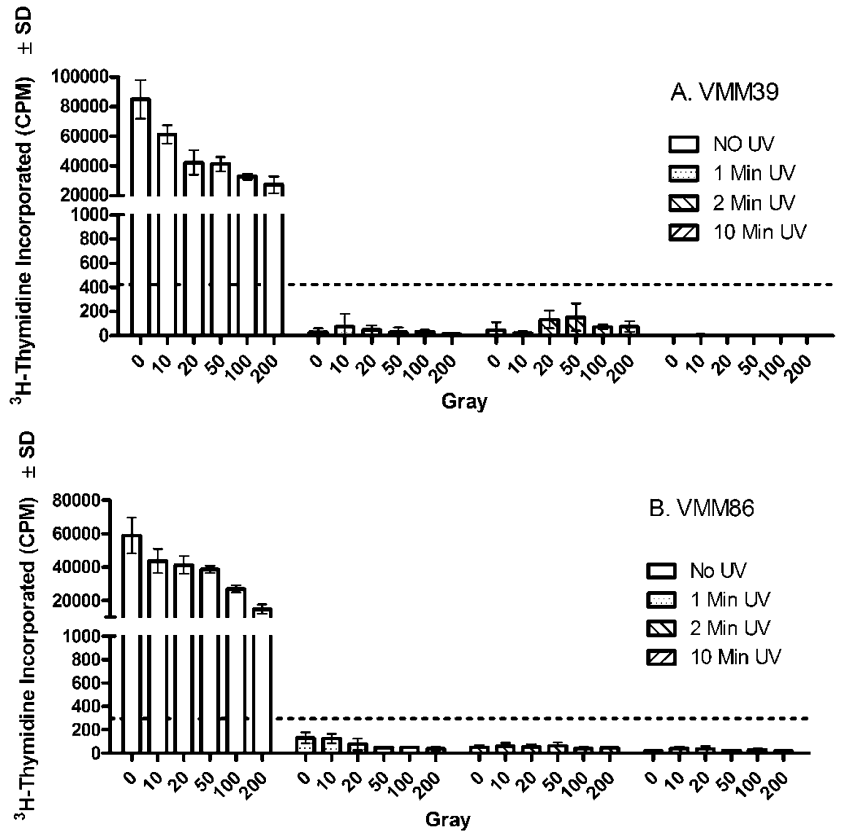

Figure 3

Control of melanoma cell line ${ }^{3} \mathrm{H}$-thymidine incorporation after combination gamma-irradiation andUVirradiation. Melanoma cell lines (A) VMM39 and (B) VMM86 were non-irradiated or treated with varying combinations of gamma-irradiation or UV-irradiation. The cell lines were then cultured in vitro for five days prior to the addition of ${ }^{3} \mathrm{H}$-thymidine for 18 to $24 \mathrm{hr}$. The dashed horizontal bar indicates $5 \%$ maximal ${ }^{3} \mathrm{H}$-thymidine incorporation.

the combination of UV- and gamma-irradiation reduced ${ }^{3} \mathrm{H}$-thymidine uptake further.

Three single cell suspensions of fresh melanoma cells were also treated individually or in combination with gammairradiation (200 Gy) and UV-irradiation (2 min) (Figure 5). Gamma-irradiation of sample VMM392 did not reduce its ${ }^{3} \mathrm{H}$-thymidine uptake below $5 \%$ of that of the non-irradiated control, while UV-irradiation either alone or in combination with gamma-irradiation reduced its ${ }^{3} \mathrm{H}$-thymidine uptake below 5\%. For each of the three samples tested, the combination of gamma-irradiation and UV-irradiation decreased ${ }^{3} \mathrm{H}$-thymidine uptake to a greater extent than did use of either form of irradiation alone.

\section{Effect of gamma-irradiation and UV-irradiation on the induction of apoptosis}

Eight hours following treatment with gamma-irradiation, UV-irradiation or a combination of both forms of radiation, the melanoma cell lines VMM39 and VMM86 were evaluated for apoptosis by caspase and DNA fragmentation assays (Figure 6A, 6B). Gamma-irradiation by itself 


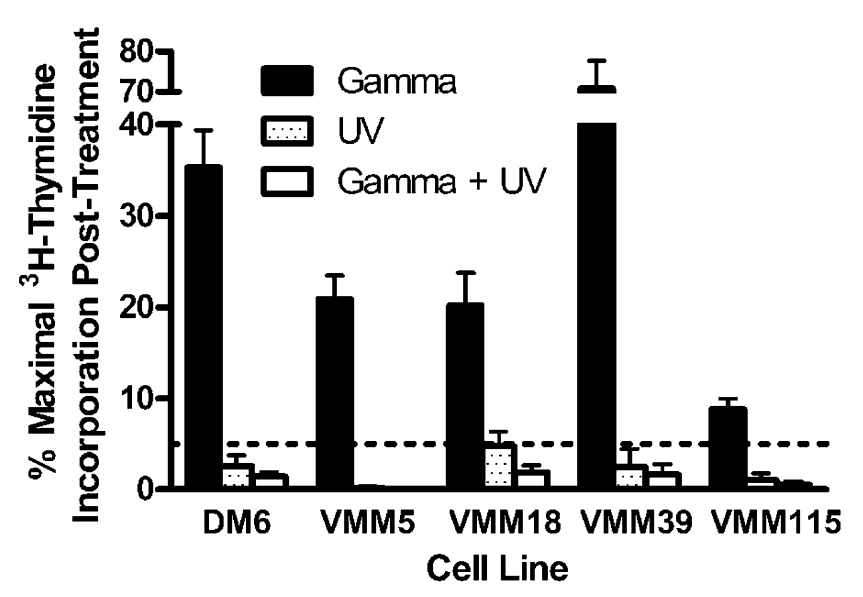

Figure 4

Control of melanoma cell line ${ }^{3} \mathrm{H}$-thymidine incorporation after combination gamma-irradiation andUVirradiation. Melanoma cell lines were non-irradiated, gamma-irradiated (200 Gy), UV-irradiated (5 min), or both gamma-irradiated (200 Gy) and UV-irradiated (5 min). The cell lines were then cultured in vitro for five days prior to the addition of ${ }^{3} \mathrm{H}$-thymidine for 18 to $24 \mathrm{hr}$. The data are presented as percent maximal ${ }^{3} \mathrm{H}$-thymidine incorporation in comparison to the non-irradiated control. The dashed horizontal bar indicates $5 \%$ maximal ${ }^{3} \mathrm{H}$-thymidine incorporation.

led to a small increase in caspase detection with melanoma line VMM39, while UV-irradiation, either alone or in combination with gamma-irradiation led to higher levels of detectable caspase with VMM39 (Figure 6A). Similar results were obtained with melanoma line VMM86 except that gamma-irradiation alone did not result in an increase in the detectable caspase. Gammairradiation by itself did not increase (VMM39) or only slightly increased (VMM86) DNA fragmentation over that seen in untreated controls (Figure 6B). UV-irradiation induced DNA fragmentation in both cell lines, and the combination of both types of radiation led to the largest increases in DNA fragmentation.

\section{Tumor viability following gamma-irradiation and UV- irradiation}

To determine the approximate time after radiation that human tumor cells remain viable, the melanoma cell line VMM39 was irradiated, cultured in vitro for up to seventynine hours, and evaluated for viability by trypan blue exclusion (Figure 7). Cells treated with gamma-irradiation alone remained greater than $80 \%$ viable seventy-nine hours post treatment and had comparable viability to that of the untreated cells. Conversely, cells treated with UVirradiation or a combination of UV- and gamma-irradiation demonstrated a marked decrease in viability within 24 hours of treatment, and were less than 35\% viable within seventy-nine hours following treatment. The mor-

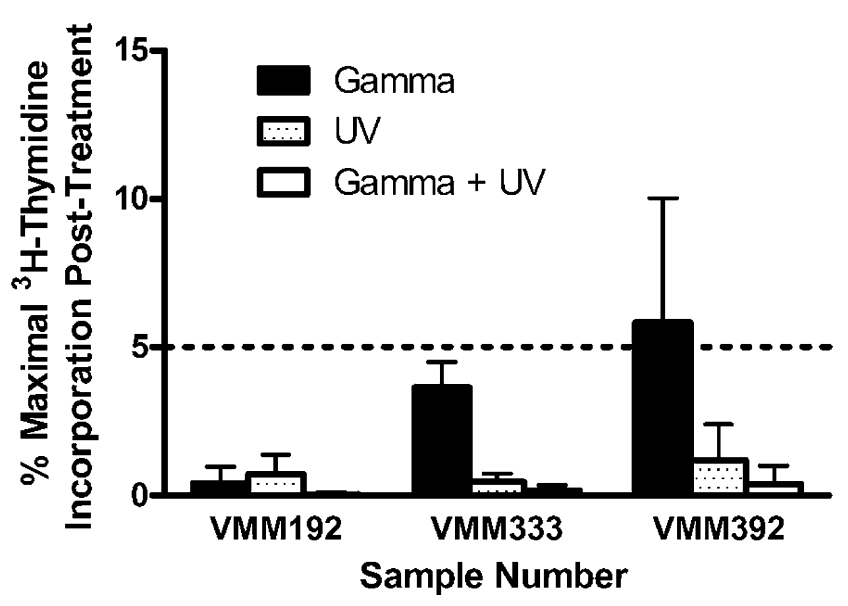

Figure 5

Control of melanoma vaccine preparation ${ }^{3} \mathrm{H}$-thymidine incorporation after combination gamma-irradiation andUV-irradiation. Melanoma cells prepared for vaccination were non-irradiated, gamma-irradiated (200 Gy), UV-irradiated (5 min), or both gamma-irradiated (200 Gy) and UV-irradiated $(5 \mathrm{~min})$. The cell lines were then cultured in vitro for five days prior to the addition of ${ }^{3} \mathrm{H}$-thymidine for 18 to $24 \mathrm{hr}$. The data are presented as percent maximal ${ }^{3} \mathrm{H}$ thymidine incorporation in comparison to the non-irradiated control. The dashed horizontal bar indicates $5 \%$ maximal ${ }^{3} \mathrm{H}$ thymidine incorporation.

phology of the treated and untreated cells five days posttreatment is consistent with the observed viability (Figure 8). The VMM39 melanoma cells remained adherent five days after gamma-irradiation, but all cells had lost adherence by five days after UV-irradiation, consistent with induction of apoptosis in the vast majority of tumor cells. Treatment of the cells with both gamma-irradiation and UV-irradiation did not produce changes in morphology or adherence that were distinguishable from UV-irradiation treatment alone.

\section{Effect of gamma-irradiation and UV-irradiation on the stability of antigenic proteins}

To evaluate if the treatment of melanoma cell lines DM6 and DM93 with gamma-irradiation and/or UV-irradiation impacts the expression of three common shared melanoma antigens (gp100, tyrosinase, MART-1) and the melanoma marker S100, the cell lines were irradiated and then cultured an additional twenty-nine hours. Cell blocks were then prepared and antigen expression determined by immunohistochemistry (Table 1). In comparison to untreated controls, the treatments, either alone or in combination, did not affect the expression of gp100, MART-1, and S100. In contrast, UV-irradiation, either alone or in combination with gamma-irradiation, rendered tyrosinase undetectable using the tyrosinase-specific antibody T311. 

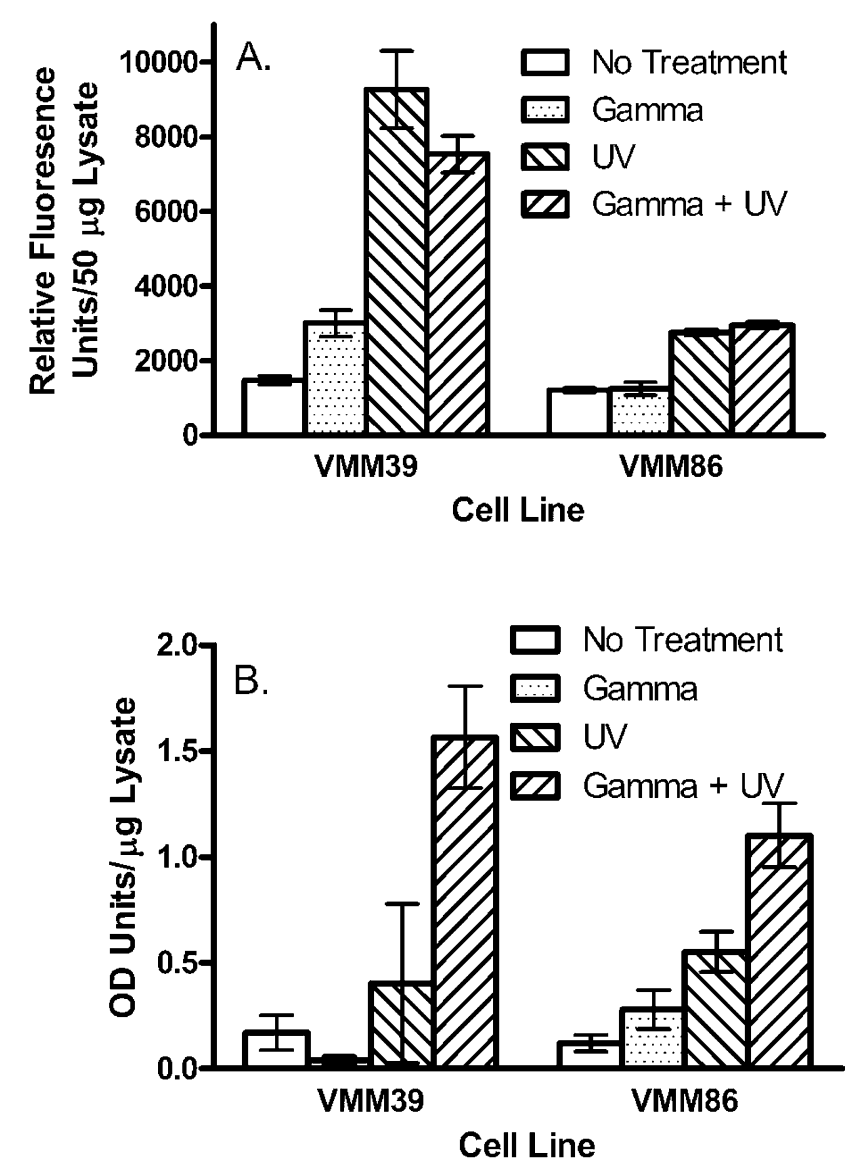

Figure 6

Induction of apoptosis in melanoma cell lines following gamma-irradiation and/or UV-irradiation.

Melanoma cells prepared for vaccination were non-irradiated, gamma-irradiated (200 Gy), UV-irradiated (5 min), or both gamma-irradiated (200 Gy) and UV-irradiated (5 min). The cell lines were then cultured in vitro for eight hours prior to assaying (A) caspase activity or (B) DNA fragmentation.

The effect of UV-irradiation on tyrosinase expression was further investigated by performing Western blot analysis (Figure 9). Cell lysates were prepared from cells treated twenty-nine hours earlier with UV-irradiation or from untreated control cells. Tyrosinase protein expression was detected in untreated DM6 and DM93 melanoma lines, with DM6 expressing higher amounts of tyrosinase than DM93. Tyrosinase protein expression was detected at significantly lower levels in the corresponding UV-irradiated cells. GAPDH expression is roughly equivalent in the different samples indicating that a similar amount of protein is present in each lane.

\section{Discussion}

The first requirement of a new therapy is that it be safe. Although cancer vaccines are generally considered safe,

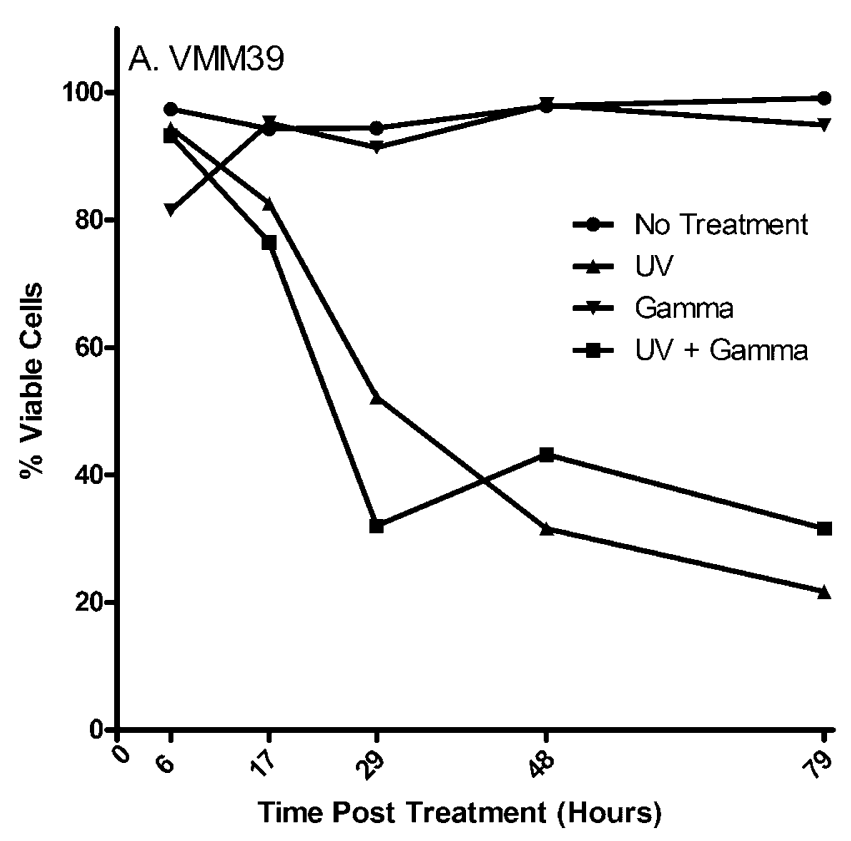

Figure 7

Melanoma cell viability after irradiation. The melanoma cell line VMM39 was evaluated by trypan blue exclusion for the persistence of viable cells at multiple time points after UV-irradiation alone (5 min), gamma-irradiation alone (200 Gy), combined UV-irradiation (5 $\mathrm{min}$ ) and gamma-irradiation (200 Gy), or no treatment.

vaccines incorporating autologous tumor carry a risk of implanting tumor cells that are capable of growth and dissemination in the patient. Such a risk has been demon-

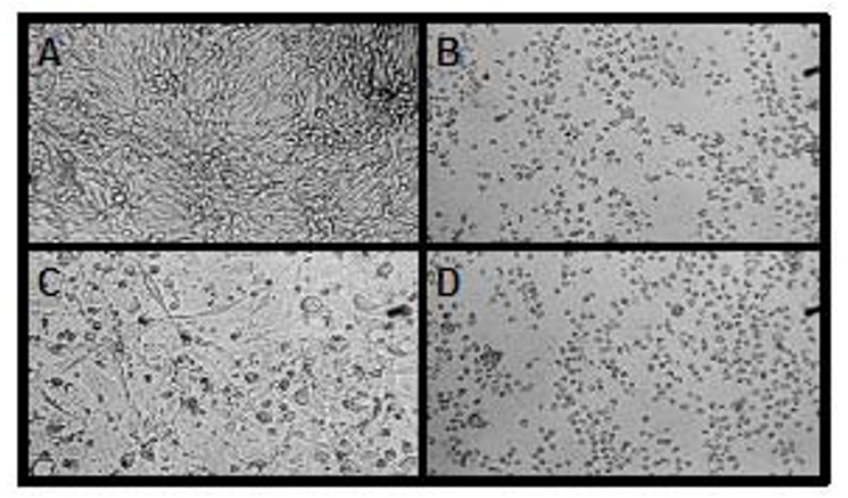

Figure 8

Adherence and morphology of melanoma cell line VMM39 following gamma-irradiation and/or UV-irradiation. VMM39 was (A) non-irradiated, (B) gamma-irradiated (200 Gy), (C) UV-irradiated (5 min), or (D) both gamma-irradiated (200 Gy) and UV-irradiated (5 min). The cell lines were then cultured in vitro for five days prior to microscopic evaluation. Representative areas of the cell culture surface are shown. 
Table I: Antigen expression in melanoma cell lines twenty nine hours following UV and/or gamma-irradiation*

\begin{tabular}{|c|c|c|c|c|c|c|c|c|}
\hline \multirow[b]{3}{*}{ Treatment } & \multicolumn{8}{|c|}{$\%$ Antigen Expression ${ }^{\dagger}$} \\
\hline & \multicolumn{2}{|c|}{ gp 100} & \multicolumn{2}{|c|}{ Tyrosinase } & \multicolumn{2}{|c|}{ MART-I/MelanA } & \multicolumn{2}{|c|}{ SI00 } \\
\hline & DM6 & DM93 & DM6 & DM93 & DM6 & DM93 & DM6 & DM93 \\
\hline Non-irradiated & $98 \%$ & $100 \%$ & $25 \%$ & $98 \%$ & $90 \%$ & $90 \%$ & $100 \%$ & $100 \%$ \\
\hline UV & $98 \%$ & $100 \%$ & $<1 \%$ & $5 \%$ & $70 \%$ & $85 \%$ & $100 \%$ & $100 \%$ \\
\hline Gamma & $100 \%$ & $100 \%$ & $30 \%$ & $98 \%$ & $80 \%$ & $85 \%$ & $100 \%$ & $100 \%$ \\
\hline UV + Gamma & $98 \%$ & $100 \%$ & $<1 \%$ & $1 \%$ & $75 \%$ & $85 \%$ & $100 \%$ & $100 \%$ \\
\hline
\end{tabular}

* Melanoma cells were non-irradiated, gamma-irradiated (200 Gy), UV-irradiated (5 min), or both gamma-irradiated (200 Gy) and UV-irradiated (5 $\min )$.

tThe percent of cells staining for gP I00 expression, tyrosinase, MART-I/MelanA, and SI00 expression was assessed by immunohistochemistry.

strated by a vast experience with transfer of tumors between syngeneic mice, but for obvious reasons, such studies have not been done in humans. There are, however, anecdotal reports that highlight the risk. These anecdotes come from older literature and involve allogeneic tumor cell transfer into patients with decreased immune competence. In one case an elderly woman was injected with her daughter's melanoma cells, which subsequently metastasized and caused her death [32]. In another case, a volunteer with impaired health developed metastases from transferred allogeneic tumor cells $[33,34]$. There are also documented cases of transfer of malignancy into an organ transplant recipient when the transplanted organ contained occult malignant cells [35]. These cases indicate

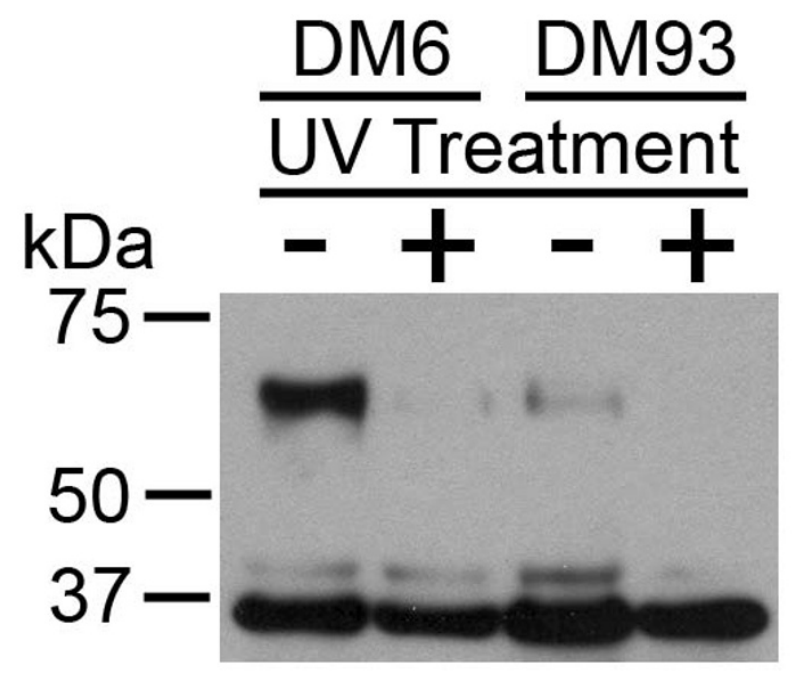

Figure 9

Tyrosinase protein expression followingUV-irradiation. Melanoma cell lines DM6 and DM93 were either nonirradiated or UV-irradiated (5 min), and then cultured an additional $29 \mathrm{~h}$. Detergent lysates were then prepared and tyrosinase expression ( $70 \mathrm{kDa})$ and GAPDH expression $(\sim 37 \mathrm{kDa})$ determined by Western blot analysis. that there is not only a theoretical risk, but also a finite risk, of tumor outgrowth in an individual receiving either autologous or allogeneic tumor cells. To guard against this risk, pretreatment of tumor cells by gamma-irradiation is a standard part of the preparation of autologous and allogeneic tumor vaccines.

There is no standard dose of gamma-irradiation with which to pre-treat tumor cells in vitro prior to their use in a vaccine, as previous studies have used gamma radiation ranging from 25 to $200 \mathrm{~Gy}$ [24-29]. In situ, gamma radiation is used clinically to control solid tumors, and is rarely able to destroy all tumor cells when delivered in multiple fractions to a total 50-60 Gy dose that is tolerated by surrounding tissues. With stereotactic radiation (gamma knife), high single doses in the range of 20 Gy are delivered to tumor cell deposits. This is much more effective at tumor destruction, but $20-25 \%$ of patients have tumors that fail to be controlled even after that large a dose of radiation $[36,37]$. Thus, there is ample evidence from clinical experience that high doses of gamma radiation may be inadequate to prevent human tumor cells from proliferating. To error on the side of caution, we chose $200 \mathrm{~Gy}$ of gamma-irradiation as the standard dose at which to pre-treat melanoma cells prior to use in an autologous vaccine preparation.

Following gamma-irradiation, the cells were tested for their ability to proliferate as measured by ${ }^{3} \mathrm{H}$-thymidine incorporation. The lot release criteria specified in the IND under which the Mel37 trial was conducted required that when measured between five and six days following gamma-irradiation, the ${ }^{3} \mathrm{H}$-thymidine incorporation of the irradiated cells be less than $5 \%$ of the ${ }^{3} \mathrm{H}$-thymidine incorporation of the non-irradiated cells. This criterion likely errs on the side of being too stringent, as cells with damaged chromosomes can incorporate ${ }^{3} \mathrm{H}$-thymidine to a limited extent even though they are incapable of proliferating, and some tumor cells damaged by radiation can continue to proliferate for a period of time before they die 
[38]. Thus, some vaccine preparations will not be used because of the inability to demonstrate the loss of proliferation in a short term assay. Alternatives to ${ }^{3} \mathrm{H}$-thymidine incorporation exist, but they are problematic as well. Trypan blue dye exclusion and counting is subject to a high rate of inter- and intra-operator error. Clonogenic assays are complicated by the fact that even in the absence of irradiation, only about $30-40 \%$ of all fresh melanoma samples yield a cell line (unpublished observations), thus lack of tumor outgrowth from a sample following irradiation doesn't necessarily reflect the results of irradiation. Likewise, xenografts into immunodeficient mice yield less than $100 \%$ outgrowth, and can require months to over a year for a tumor to become established [39].

When tumor cells from thirty-three melanoma patients were gamma-irradiated and subsequently tested for ${ }^{3} \mathrm{H}$ thymidine incorporation, eight of the preparations did not meet the release criteria (Figure 1). Five of these eight samples were among the nine samples with the lowest ${ }^{3} \mathrm{H}$ thymidine incorporation. This observation is consistent with that fact that cells do not always die immediately following radiation treatment but may first need to undergo several rounds of cell division as their genome becomes increasingly unstable [40]. Cells incorporating little ${ }^{3} \mathrm{H}-$ thymidine are unlikely to be undergoing mitosis at a high rate and thus less likely to acquire the genomic instability necessary to lead to cell death. Although less often than cells with a low proliferative capacity, some samples with an initial high proliferative capacity clearly retained the ability to proliferate following gamma-irradiation. These results indicate that treatment with $200 \mathrm{~Gy}$ of gamma irradiation is not always sufficient to block the incorporation of ${ }^{3} \mathrm{H}$-thymidine into the DNA of melanoma samples, and that approximately $25 \%$ of the samples will fail a release criterion that requires the ${ }^{3} \mathrm{H}$-thymidine incorporation of the gamma-irradiated sample to be less than $5 \%$ of that obtained with the corresponding non-irradiated sample. Of the twenty-eight vaccine lots that were released for immunization, none resulted in outgrowth of the tumor at the site of immunization. Interestingly, while other studies have treated the autologous tumor to be used in vaccines with 25 to $200 \mathrm{~Gy}$ of irradiation [24-29], none of the studies apparently incorporated a release criterion demonstrating that the irradiation had substantially impacted on the ability of the cells to proliferate. Also, none of those studies reported outgrowth of the immunizing tumor at the injection site.

Although it is feasible to measure post-radiation ${ }^{3} \mathrm{H}$-thymidine incorporation capacity and to exclude patients from protocols whose tumors demonstrate incorporation after gamma-irradiation as was done for the Mel37 clinical trial, we wanted to develop a protocol that would more reliably block ${ }^{3} \mathrm{H}$-thymidine incorporation in the irradi- ated tumor cells. UV-irradiation, which is known to induce apoptosis [40-42], was therefore tested as an adjunct to gamma-irradiation.

Treatment of melanoma cell lines and patient samples with UV-irradiation $\left(168 \mathrm{~mJ} / \mathrm{cm}^{2}\right.$ UVA and $\left.52 \mathrm{~mJ} / \mathrm{cm}^{2}\right)$ alone or in combination with gamma-irradiation $(200$ Gy) is more effective at reducing ${ }^{3} \mathrm{H}$-thymidine incorporation than is treatment with gamma-irradiation alone (Figure $3,4,5$ ). This finding is consistent with the results of the cell viability assay which demonstrates that UV-irradiation either alone or in combination with gamma-irradiation induces a significant amount of death one day following treatment, while gamma-irradiation alone has no effect on viability at least through three days following treatment (Figure 7). Although in most cases UV-irradiation may be sufficiently effective on its own to reduce ${ }^{3} \mathrm{H}$ thymidine incorporation below that of $5 \%$ of the nonirradiated control, the combination of gamma-irradiation and UV-irradiation adds an extra layer of security in minimizing the possibility of tumor outgrowth following vaccination.

Gamma-irradiation can induce apoptosis in tumor cells $[40,43,44]$, but 200 Gy of gamma-irradiation induced little to no apoptosis in the melanoma cell lines VMM39 and VMM86 when they were tested eight hours post-irradiation (Figure 6). This was true whether caspase was measured as an indicator of early apoptosis or DNA fragmentation was measured as an indicator of late apoptosis. Conversely, UV-irradiation, either alone or in combination with gamma-irradiation, induced apoptosis as measured by both the caspase and DNA fragmentation assays. Thus, the addition of UV-irradiation to the vaccine preparation protocol not only decreases the ${ }^{3} \mathrm{H}$-thymidine incorporation of the tumor cells such that it is more likely they will pass the release criteria, but it also enhances apoptosis which may increase the likelihood of uptake by dendritic cells with the subsequent presentation of tumor antigens [45].

A potential consequence of tumor cells beginning to undergo apoptosis and subsequent death is the degradation of cellular proteins by lysosomal proteases which could destroy antigens that would otherwise be acquired by dendritic cells. This in turn may prevent the subsequent cross-priming of $\mathrm{T}$ cells $[46,47]$. Therefore, we used immunohistochemistry to assess the expression of typical cellular proteins after gamma-irradiation and UV-irradiation (Table 1). Expression of gp100, MART-1/MelanA, and S100 was unaffected by gamma- or UV-irradiation. Conversely, tyrosinase expression was decreased by UVirradiation alone or in combination with gamma-irradiation, but not by gamma-irradiation alone. T311, the antibody used to detect tyrosinase, binds to a linear epitope 
located within amino acids $233-247$ of the protein [48]. Therefore, the most likely explanations for a loss of reactivity in immunohistochemistry is that the linear epitope has been cleaved and is no longer recognized by the antibody, or that the protein has been degraded to such an extent that proteolytic fragments containing the epitope no longer exist. To further investigate the possibility that the protein has been degraded we performed a Western blot analysis using the polyclonal antibody $\mathrm{H}-109$ which was raised against amino acids $421-529$ at the C-terminus of the tyrosinase protein (product insert). This analysis also showed that tyrosinase expression was greatly reduced in UV-irradiated cells. Taken together, these results suggest that the tyrosinase protein is not merely unfolded, but has undergone significant degradation. Should $\mathrm{T}$ cell stimulation occur as a result of recognition of processed peptide on the irradiated tumor cells rather than through cross priming on dendritic cells, it is possible that the loss of the epitope recognized by the antibody could be accompanied by an increase in peptide presentation by class I MHC molecules as the denatured/degraded protein may be processed more efficiently by proteasomes. These results indicate that additional studies are warranted to determine how irradiation, apoptosis, and necrosis affect antigen expression and the activation of antigen-specific $T$ cells.

\section{Conclusion}

When autologous melanoma cell vaccines are treated with 200 Gy of gamma-irradiation, $25 \%$ of them fail a lot release criterion requiring that ${ }^{3} \mathrm{H}$-thymidine incorporation of the irradiated samples be less than $5 \%$ of that seen in the non-irradiated controls. This release criterion could be met in all samples tested, however, when gamma-irradiation of the cells was supplemented with UV-irradiation. The results also indicate that UV-irradiation resulted in the degradation of at least one antigen in the treated cells, while preserving at least three other antigens. There are currently no standard lot release criteria for autologous melanoma vaccines, but we hope the current findings are informative toward future cell-based vaccine development.

\section{Competing interests}

The authors declare that they have no competing interests.

\section{Authors' contributions}

DHD, EMS, CED, ARC performed the experiments and reviewed/edited the manuscript. KTH analyzed and interpreted the data, and co-wrote the manuscript. KACB contributed to the conception of the experiments and reviewed/edited the manuscript. JWP and MWT performed the immunohistochemistry experiments and reviewed/edited the manuscript. CLS conceived the project and contributed to its design, analyzed and inter- preted the data, and co-wrote the manuscript. All authors read and approved the final manuscript.

\section{Acknowledgements}

The authors would like to thank Cheryl Murphy for performing the Western blots. This study was supported by $\mathrm{NIH} / \mathrm{NCl}$ grant R2I CA89937 (to CLS). Support was also provided by the University of Virginia Cancer Center Support Grant (NIH/NCI P30 CA44579, Clinical Trials Office, Tissue Procurement Facility); and the UVA General Clinical Research Center (NIH 5 MOI RR00847).

\section{References}

I. Rosenberg SA: A new era for cancer immunotherapy based on the genes that encode cancer antigens. Immunity 1999, I0:28I-287.

2. Eynde BJ Van den, Bruggen $P$ van der: $\mathbf{T}$ cell defined tumor antigens. Curr Opin Immunol 1997, 9:684-693.

3. Castelli C, Rivoltini L, Andreola G, Carrabba M, Renkvist N, Parmiani G: T-cell recognition of melanoma-associated antigens. J Cell Physiol 2000, I 82:323-331.

4. Zendman AJ, de Wit NJ, van Kraats AA, Weidle UH, Ruiter DJ, van Muijen GN: Expression profile of genes coding for melanoma differentiation antigens and cancer/testis antigens in metastatic lesions of human cutaneous melanoma. Melanoma Res 200 I, I I :45 I-459.

5. Hogan KT, Coppola MA, Gatlin CL, Thompson LW, Shabanowitz J, Hunt DF, Engelhard VH, Ross MM, Slingluff CL: Identification of novel and widely expressed cancer/testis gene isoforms that elicit spontaneous cytotoxic $T$ lymphocyte reactivity to melanoma. Cancer Res 2004, 64: I I57-I I63.

6. de Vries TJ, Smeets M, de Graaf R, Hou-Jensen K, Brocker EB, Renard N, Eggermont AM, van Muijen GN, Ruiter DJ: Expression of gp l 00, MART-I, tyrosinase, and $\mathrm{SI} 00$ in paraffin-embedded primary melanomas and locoregional, lymph node, and visceral metastases: implications for diagnosis and immunotherapy. A study conducted by the EORTC Melanoma Cooperative Group. J Pathol 200I, I93:13-20.

7. Cormier JN, Hijazi YM, Abati A, Fetsch P, Bettinotti M, Steinberg SM, Rosenberg SA, Marincola FM: Heterogeneous expression of melanoma-associated antigens and HLA-A2 in metastatic melanoma in vivo. Int J Cancer 1998, 75:517-524.

8. Cormier JN, Abati A, Fetsch P, Hijazi YM, Rosenberg SA, Marincola $\mathrm{FM}$, Topalian SL: Comparative analysis of the in vivo expression of tyrosinase, MART-I/Melan-A, and gpl00 in metastatic melanoma lesions: implications for immunotherapy. J Immunother 1998, 21:27-31.

9. Riker A, Cormier J, Panelli M, Kammula U, Wang E, Abati A, Fetsch $\mathrm{P}$, Lee KH, Steinberg S, Rosenberg S, Marincola F: Immune selection after antigen-specific immunotherapy of melanoma. Surgery 1999, I 26: I 12-120.

10. de Vries T], Fourkour A, Wobbes T, Verkroost G, Ruiter DJ, van Muijen GN, de Vries TJ, Fourkour A, Wobbes T, Verkroost G, Ruiter DJ, van Muijen GN: Heterogeneous expression of immunotherapy candidate proteins gp I 00, MART-I, and tyrosinase in human melanoma cell lines and in human melanocytic lesions. Cancer Res 1997, 57:3223-3229.

II. Slingluff CL Jr, Colella TA, Thompson L, Graham DD, Skipper JC, Caldwell J, Brinckerhoff L, Kittlesen DJ, Deacon DH, Oei C, Harthun NL, Huczko EL, Hunt DF, Darrow TL, Engelhard VH: Melanomas with concordant loss of multiple melanocytic differentiation proteins: immune escape that may be overcome by targeting unique or undefined antigens. Cancer Immunol Immunother 2000, 48:66I-672.

12. Hogan KT, Eisinger DP, Cupp SB 3rd, Lekstrom KJ, Deacon DD, Shabanowitz J, Hunt DF, Engelhard VH, Slingluff CL Jr, Ross MM: The peptide recognized by HLA-A68.2-restricted, squamous cell carcinoma of the lung-specific cytotoxic $\mathbf{T}$ lymphocytes is derived from a mutated elongation factor $\mathbf{2}$ gene. Cancer Res 1998, 58:5144-5I50.

13. Segal NH, Parsons DW, Peggs KS, Velculescu V, Kinzler KW, Vogelstein B, Allison JP: Epitope landscape in breast and colorectal cancer. Cancer Res 2008, 68:889-892. 
14. Parmiani G, De Filippo A, Novellino L, Castelli C: Unique Human Tumor Antigens: Immunobiology and Use in Clinical Trials. J Immunol 2007, I 78:1975-1979.

15. Berd D, Maguire HC Jr, Mastrangelo MJ: Induction of cell-mediated immunity to autologous melanoma cells and regression of metastases after treatment with a melanoma cell vaccine preceded by cyclophosphamide. Cancer Res 1986 , 46:2572-2577.

16. Berd D, Maguire HC Jr, McCue P, Mastrangelo MJ: Treatment of metastatic melanoma with an autologous tumor-cell vaccine: Clinical and immunologic results in 64 patients. J Clin Oncol 1990, 8: 1858-1867.

17. Nair SK, Morse M, Boczkowski D, Cumming RI, Vasovic L, Gilboa E, Lyerly HK: Induction of tumor-specific cytotoxic $T$ lymphocytes in cancer patients by autologous tumor RNAtransfected dendritic cells. Ann Surg 2002, 235:540-549.

18. Heiser A, Maurice MA, Yancey DR, Wu NZ, Dahm P, Pruitt SK, Boczkowski D, Nair SK, Ballo MS, Gilboa E, Vieweg J: Induction of polyclonal prostate cancer-specific CTL using dendritic cells transfected with amplified tumor RNA. J Immunol 200I, 166:2953-2960.

19. Testori A, Richards J, Whitman E, Mann GB, Lutzky J, Camacho L, Parmiani G, Tosti G, Kirkwood JM, Hoos A, Yuh L, Gupta R, Srivastava PK, Group CS: Phase III comparison of vitespen, an autologous tumor-derived heat shock protein gp96 peptide complex vaccine, with physician's choice of treatment for stage IV melanoma: the C-I00-2I Study Group. J Clin Oncol 2008, 26:955-962

20. Belli F, Testori A, Rivoltini L, Maio M, Andreola G, Sertoli MR, Gallino G, Piris A, Cattelan A, Lazzari I, Carrabba M, Scita G, Santantonio C Pilla L, Tragni G, Lombardo C, Arienti F, Marchiano A, Queirolo P, Bertolini F, Cova A, Lamaj E, Ascani L, Camerini R, Corsi M, Cascinelli $\mathrm{N}$, Lewis J], Srivastava P, Parmiani G: Vaccination of metastatic melanoma patients with autologous tumor-derived heat shock protein gp96-peptide complexes: clinical and immunologic findings[see comment][erratum appears in J Clin Oncol 2002 Dec I;20(23):46 I 0]. J Clin Oncol 2002, 20:4 I69-4I80.

2I. O'Rourke MGE, Johnson M, Lanagan C, See J, Yang J, Bell JR, Slater GJ, Kerr BM, Crowe B, Purdie DM, Elliott SL, Ellem KAO, Schmidt CW Durable complete clinical responses in a phase I/II trial using an autologous melanoma cell/dendritic cell vaccine. Cancer Immunol Immunother 2003, 52:387-395.

22. Nestle FO, Alijagic S, Gilliet M, Sun Y, Grabbe S, Dummer R, Burg G Schadendorf D: Vaccination of melanoma patients with peptide- or tumor lysate-pulsed dendritic cells. Nat Med 1998 , 4:328-332.

23. Thumann P, Moc I, Humrich J, Berger TG, Schultz ES, Schuler G, Jenne L: Antigen loading of dendritic cells with whole tumor cell preparations. J Immunol Methods 2003, 277:1-16.

24. Berd D, Kairys J, Dunton C, Mastrangelo MJ, Sato T, Maguire HC Jr: Autologous, hapten-modified vaccine as a treatment for human cancers. Semin Oncol 1998, 25:646-653.

25. Lotem M, Peretz T, Drize O, Gimmon Z, Ad EI D, Weitzen R, Gold berg H, Ben David I, Prus D, Hamburger T, Shiloni E: Autologous cell vaccine as a post operative adjuvant treatment for highrisk melanoma patients (AJCC stages III and IV). The new American Joint Committee on Cancer. Br J Cancer 2002, 86: $1534-1539$

26. Kusumoto $M$, Umeda S, Ikubo A, Aoki $Y$, Tawfik O, Oben R, Williamson S, Jewell W, Suzuki T: Phase I clinical trial of irradiated autologous melanoma cells adenovirally transduced with human GM-CSF gene. Cancer Immunol Immunother 2001, 50:373-38I.

27. Harris JE, Ryan L, Hoover HC Jr, Stuart RK, Oken MM, Benson AB 3rd, Mansour E, Haller DG, Manola J, Hanna MG Jr: Adjuvant active specific immunotherapy for stage II and III colon cancer with an autologous tumor cell vaccine: Eastern Cooperative Oncology Group Study E5283. J Clin Oncol 2000, I 8: | 48- I57.

28. Abdel-Wahab Z, Weltz C, Hester D, Pickett N, Vervaert C, Barber JR, Jolly D, Seigler HF: A Phase I clinical trial of immunotherapy with interferon-gamma gene-modified autologous melanoma cells: monitoring the humoral immune response[erratum appears in Cancer 1999 Oct I;86(7): I380]. Cancer 1997, 80:401-4I2.

29. Berd D, Sato T, Mastrangelo MJ: Effect of the dose and composition of an autologous hapten-modified melanoma vaccine on the development of delayed-type hypersensitivity responses. Cancer Immunol Immunother 2002, 5 I:320-326.

30. Denlinger CE, Keller MD, Mayo MW, Broad RM, Jones DR: Combined proteasome and histone deacetylase inhibition in nonsmall cell lung cancer. Journal of Thoracic \& Cardiovascular Surgery 2004, I 27:1078-1086.

31. Harlow E, Lane D: Antibodies: A Laboratory Manual Ist edition. Cold Spring Harbor: Cold Spring Harbor Laboratory Press; 1988:450.

32. Scanlon EF, Hawkins RA, Fox WW, Smith WS: Fatal homotransplanted melanoma: a case report. Cancer 1965, I 8:782-789.

33. Southam CM: Homotransplantation of human cell lines. Bull $N$ Y Acad Med 1958, 34:416-423.

34. Southam CM, Moore AE: Induced immunity to cancer cell homografts in man. Ann N Y Acad Sci 1958, 73:635-653.

35. Penn I: Malignant melanoma in organ allograft recipients. Transplantation 1996, 6 I:274-278

36. Amendola BE, Wolf AL, Coy SR, Amendola M, Bloch L: Gamma knife radiosurgery in the treatment of patients with single and multiple brain metastases from carcinoma of the breast. Cancer J 2000, 6(2):88-92.

37. Sansur CA, Chin LS, Ames JW, Banegura AT, Aggarwal S, Ballesteros $M$, Amin P, Simard JM, Eisenberg H: Gamma knife radiosurgery for the treatment of brain metastases. Stereotactic \& Functional Neurosurgery 2000, 74:37-5I.

38. Seymour CB, Mothersill C, Alper T: High yields of lethal mutations in somatic mammalian cells that survive ionizing radiation. Int J Radiat Biol Relat Stud Phys Chem Med 1986, 50(I): $167-179$

39. Morton CL, Houghton PJ: Establishment of human tumor xenografts in immunodeficient mice. Nature Protocols 2007 , 2:247-250.

40. Verheij M, Bartelink H: Radiation-induced apoptosis. Cell \& Tissue Research 2000, 301:133-142.

4l. Kulms D, Schwarz T: Molecular mechanisms of UV-induced apoptosis. Photodermatology, Photoimmunology \& Photomedicine 2000 , 16:195-201.

42. Kulms D, Schwarz T: Independent contribution of three different pathways to ultraviolet-B-induced apoptosis. Biochem Pharmacol 2002, 64:837-84I.

43. Illidge TM: Radiation-induced apoptosis. Clin Oncol (R Coll Radiol) 1998, 10:3-13.

44. Jonathan EC, Bernhard EJ, McKenna WG: How does radiation kil cells? Curr Opin Chem Biol 1999, 3:77-83.

45. Hatfield P, Merrick A, Harrington K, Vile R, Bateman A, Selby P, Melcher A: Radiation-induced cell death and dendritic cells: potential for cancer immunotherapy? Clin Oncol (R Coll Radiol) 2005, I7:I-II.

46. Cresswell $P$, Ackerman AL, Giodini A, Peaper DR, Wearsch PA Mechanisms of $\mathrm{MHC}$ class l-restricted antigen processing and cross-presentation. Immunol Rev 2005, 207:| 45-I57.

47. Rock KL, Shen L: Cross-presentation: underlying mechanisms and role in immune surveillance. Immunol Rev 2005, 207: $166-183$.

48. Willers J, Lucchese A, Mittelman A, Dummer R, Kanduc D: Definition of anti-tyrosinase MAb T3 I I linear determinant by proteome-based similarity analysis. Exp Dermatol 2005, | 4:543-550.

\section{Pre-publication history}

The pre-publication history for this paper can be accessed here:

http://www.biomedcentral.com/1471-2407/8/360/pre pub 